\title{
Formål for muslimske friskoler i Danmark - udviklinger i formålser- klæringer og vedtægter $i$ danske friskoler for muslimske børn
}

\author{
Af Tallat Shakoor
}

\section{Resumé}

Artiklen beskriver og kategoriserer formålserklæringer i 23 danske friskoler for muslimske børn i perioden 1980 til 2005, og finder at der er sket en udvikling i, hvorledes skolernes islamiske grundlag italesættes i løbet af denne 25 -årige periode. Tidligt i perioden indskrænkes islams betydning til klasseværelset, men udbredes i løbet af 1990'erne til at omfatte elevens almene dannelse. Denne udvikling gives anledning til nogle indledende overvejelser over terminologien i forbindelse med begrebsafklaringen af de såkaldte "muslimske friskoler".

\section{Indledning}

Den danske friskoletradition har generelt været objekt for bl.a. adskillige historiske studier. ${ }^{1}$ Men verden venter endnu på et historisk studie af danske friskoler for muslimske børn, på trods af at friskolerne repræsenterer et historisk knudepunkt for de muslimske indvandreres uddannelseshistorie, organisering og udvikling i det danske samfund. ${ }^{2}$ Årsagen til denne mangel skyldes primært, at kilderne er svært tilgængelige. Dels fordi de befinder sig i forskellige ministerielle arkiver og i eksisterende og nedlagte biblioteker. Og dels fordi en hel del må forventes enten at være gået tabt $\mathrm{i}$ arkiverne eller kun eksistere i hukommelsen blandt nogle af de involverede parter. Nærværende artikel beskæftiger sig med et lille hjørne af dette arkivmateriale, nemlig friskolernes vedtægter, nærmere bestemt formålsparagrafferne for 23 danske friskoler for muslimske børn i perioden mellem 1980 og 2005. ${ }^{3}$ I forskningen om de danske friskoler for muslimske børn er der ikke udført et selvstændigt studie af friskolernes vedtægter, om end vedtægterne har været benævnt i flere forskningsmæssige sammenhænge. ${ }^{4}$ Formålsparagraffer er stedet, hvori skolens grundholdning præsenteres i overensstemmelse med princippet om ideologisk frihed, som er det betydeligste af de fem frihedsprincipper i friskolernes frihed. ${ }^{5}$ Princippet om ideologisk frihed knytter sig dels til forestillingen om forældrenes ansvar til at sørge for deres børns undervisning, forældreretten - dels til forestillingen om mindretalsretten, hvorved mindretallet har en principiel ret til at udfolde deres meninger og handlinger, på trods af at de står i modsætning til flertallets. Formålsparagrafferne er centrale for forståelsen af en friskoles grundlæggende ideologiske linje. I forhold til de danske friskoler for muslimske børn er det formålsparagrafferne, som leverer rationalet for, at der kan tilbydes undervisning i islam. Igennem en identificering af hvilke friskoler som har formålsparagraffer, hvor islam nævnes, er det muligt at få et klarere billede af, hvor 
stor en rolle islam formelt og principielt har spillet for de muslimske immigranter i perioden 1980 til 2005.

Siden begyndelsen af 1990'erne har friskolerne tildraget sig opmærksomhed i den offentlige danske avispresse, hvori skolerne har dannet tema af flere omgange. ${ }^{6}$ De danske friskoler for muslimske børn er væsensforskellige fra andre former for islamiske uddannelsesinstitutioner i vesten og i den muslimske verden, ${ }^{7}$ idet de er baseret på den danske friskoletradition og drives efter den danske friskolelov. De fleste friskoler tilbyder undervisning i islam, og en del af skolerne benævner islam i deres formålsparagraffer. Men vægtningen af islam varierer fra skole til skole og kan som sådan ikke siges at være et primært karakteristika ved friskolerne. Årsagerne til denne opmærksomhed har dels været, at nogle friskoler har haft svært ved at stå mål med folkeskolens undervisningsmæssige standard og er blevet frataget deres statslige tilskud. Men samtidig figurerer skolerne også i den offentlige debat som et eksempel på en forestilling om en kløft mellem islam og det danske samfund. ${ }^{8}$ Disse saglige og mindre saglige kritikker har løbende bidraget til og medført en skærpelse af tilsynet med de muslimske friskoler fra Undervisningsministeriet.

Forskningen inden for de friskolerne afspejler til en vis grad denne fortsatte debat, og flere studier har også forsøgt at stille skarpt på nogle af de emner, som har optaget den brede offentlighed. Forskellige emner som friskolernes betydning for elevernes kulturelle, religiøse og civile identitetsdannelse, islamforståelse, islamfortolkning og demokratiopfattelse inden for murene har været fokus for en del studier både i Danmark og i Sverige. ${ }^{9}$ Friskolerne har vist sig at være et aktuelt og påtrængende emne, som igen og igen fremprovokerer studier, hvilket har kastet en del lys over fænomenet også i udlandet. ${ }^{10}$ Antropologen Haaber Ihle har udført et grundlæggende studie af muslimske friskoler i det nye årtusind baseret på antropologisk feltarbejde i tre friskoler, som adskiller sig fra hinanden i forhold til skolens alder, længden og karakteren af forældrenes ophold i Danmark og den etniske komposition af elever. Haaber Ihle har skitseret en typologi, som placerer skolerne i tre grupper: skoler, som primært servicerer en særlig etnisk gruppe; skoler, som primært servicerer elever og forældre med arabiske dialekter som modersmål, og skoler, som primært relaterer sig til islam enten i bred forstand eller inden for en særlig fortolkningstradition. Samtidig beskriver Haaber Ihle skolerne som et "samlingspunkt for forældre med mere eller mindre udtalt indvandrerbaggrund, der hyl- 
der en fælles religiøs tradition indenfor islam [...]. Man kan konkludere, at den muslimske friskole er under indflydelse af forældrenes livsvilkår, livsstil og de islamiske fortolkningstraditioner, de dels bringer med sig og dels møder i den europæiske kontekst". ${ }^{11}$ Haaber Ihle beskriver skolerne som både differentierede i forældrepopulationer og fælles i forældrenes overordnede fokus. Dette giver et billede af friskolernes kompleksitet, men problematiserer yderligere terminologien omkring friskolerne.

De såkaldte muslimske friskoler er et fænomen, som det har vist sig meget problematisk at navngive korrekt. Skolernes populationer kan i varierende grad beskrives som friskoler for indvandrere eller efterkommere, børn med anden etnisk baggrund end dansk, muslimske børn eller børn af denne eller hin nationalitet. Årsagen til denne manglende begrebsafklaring er, at friskolerne er så tæt forbundet med immigranters tilstedeværelse og ændres med immigranternes ændring i selvopfattelse, status og statsborgerskab. Men ikke desto mindre er termen "muslimske friskoler" en sproglig upræcis term, eftersom skolerne er baseret på den danske friskolelov. Termen giver det fejlagtige indtryk, at skolernes primære egenskab er, at de muslimske. Skolernes primære egenskab er, at de er skoler, som tilbyder undervisning i overensstemmelse med dansk friskolelov. Det synes at være en mere præcis beskrivelse af fænomenet at understrege skolernes danskhed, idet skolerne er etableret på og reguleres efter den danske friskolelov. Samtidig servicerer skolerne først og fremmest muslimske forældre, hvorfor majoriteten af elevpopulationerne er muslimer. Med dette i mente er det mere præcist at beskrive skolerne som danske friskoler for muslimske elever.

\section{Baggrunden for de danske friskoler for muslimske børn i Danmark}

Behovet for disse friskoler opstod først hos de muslimske migrationspopulationer, da familierne blev familiesammenført med de mandlige arbejdsmigranter i 1970'erne, hvorfor den første friskole så dagens lys i 1978. Familiesammenføringerne spillede en afgørende rolle i grundlæggelsen af de første indvandrerfriskoler, da der igennem familiesammenføring ankom børn til Danmark i den undervisningspligtige alder. Med familiesammenføringerne steg efterspørgslen på undervisning i islam og modersmålsundervisning. Således blev behovet for at udvide spændvidden for organisering hos de muslimske immigranter mere presserende, og med en til dette behov utilstrækkelig offentlig dansk skole tog ønsket om indvandrerfriskoler mere og mere form i den anden halvdel af 1970'erne. Motivationen bag etableringen af disse tidlige skoler var opdelt i praktiske, 
kulturelle og religiøse samt migrationsrelaterede hensyn. For det første var der et ønske om en skole, hvor børnene kunne modtage undervisning i modersmål, religion og fag, som almindeligvis tilbydes i folkeskolen. For det andet var friskolernes religionsundervisning stærkt farvet af, at initiativtagere, administration og forældre selv var immigranter fra islamdømmer, og undervisningen i islam i disse tidlige år var stærkt præget af de dominerende religiøse traditioner i immigranternes hjemlande. ${ }^{12}$ For det tredje var der en generel forventning til opholdet i Danmark som midlertidigt, hvilket betød, at skolernes undervisning i modersmål og religion var tænkt som en grundlæggende indføring i sprog og religion, som med tiden skulle videreføres i skoler i forældrenes hjemlande. ${ }^{13}$

\section{Vedtægter og formålsparagraffer som kildemateriale}

Vedtægten er institutionens grundlov. Dens formål er at fastlægge institutionens formål samt procedureregler for ledelsens adfærd og beslutninger i det daglige og i forbindelse med institutionens ophør. For at være kvalificeret til at modtage statslig støtte er det nødvendigt for en skole at formulere og vedtage nogle juridiske retningslinjer for den generelle skoledrift. Disse retningslinjer er nedlagt i vedtægterne, hvoraf formålsparagrafferne udgør et vigtigt område.

Vedtægterne i dette studie stammer fra flg. 23 skoler (samt etableringsår): Al-Aqsa (1980), DIA Privatskole (1981); Samid Skolen (1981), Den Islamiske Safwa (1983); Jinnah Int. School (1984), Iqbal Int. School (1986), Ahi Evran Int. School (1988), Marokkansk-danske skole 1991), Al-Hikma (1993), Hay Skolen (1993), Lykkeskolen (1995), Æra Skolen (1995), Manarul-Huda (1995), Al-Huda (1996), Sjællands Privatskole (?) (1997), Al-Salahiya (1996), Selam Friskole (1997), Den Moderne Kulturelle Skole (1998), Al-Hilal (1998), Al-Kownain (2001), Fredsskolen (2003), Iqra Privatskole (2005) og Ørnevejens friskole (2005). Siden 1978 har der eksisteret lidt over tredive friskoler for muslimske børn, hvilket betyder, at nærværende studie repræsenterer ca. 70 pct. af de hidtil eksisterende skoler. Formålsparagrafferne varierer i de 23 vedtægter, men der er dog fællestræk. Generelt set indeholder alle formålsparagrafferne både lovpligtige formålsartikler og selvstændigt formulerede formålsartikler. Gennemsnitligt indeholder formålsparagrafferne fire artikler, hvoraf mindst én er lovpligtig. Det er de selvstændigt formulerede formålsparagraffer, der vil blive fokuseret på her. Formålsparagrafferne varierer i forhold til hinanden i længde og sprogbrug, om end der samlet set 
er en vis genkendelighed i paragraffernes enkelte artikler, eftersom der i forskellige paragraffer optræder en del standardformuleringer, som går igen.

\section{Friskoleloven i formålsparagrafferne}

Først og fremmest genfindes de samme lovpligtige formuleringer i friskolernes formålsparagraffer, nemlig det grundlovsbaserede krav (§76) i friskoleloven (§ 1, stk 2) om, at undervisningen skal "stå mål med, hvad der almindeligvis kræves i folkeskolen", hvilket betyder noget i retning af, at friskolerne skal kunne leve op til eller være lige så god som den danske folkeskole. ${ }^{14}$ Eftersom de fleste af de benævnte 23 skoler er etableret før 2004, er § 1, stk. 2 den hyppigst refererede paragraf i skolernes formålsartikler. 2004 medførte indgreb på friskoleområdet, hvilket bl.a. betød, at friskolelovens $\S 1$, stk. 2 undergik væsentlige ændringer. Først og fremmest medførte ændringerne en væsentlig tilføjelse af friskolernes § 1, stk. 2, som pålægger friskolerne, at de:

[...] skal efter deres formål og i hele deres virke forberede eleverne til at leve i et samfund som det danske med frihed og folkestyre samt udvikle og styrke elevernes kendskab til og respekt for grundlæggende friheds- og menneskerettigheder, herunder ligestilling mellem kønnene. (Bekendtgørelse af lov om friskoler og private grundskoler m.v., § 1, stk. 2).

Denne tilføjelse betød en lovpligtig udvidelse af friskolernes vedtægter. Skoler, som er etableret efter 2004, har også i en vis grad inkorporeret teksten i deres formålsparagraffer. Det fremgår endvidere af Undervisningsministeriets vedtægtsvejledning, ${ }^{15}$ at vedtægterne skal indeholde en fast formulering, som bl.a. inkorporerer ovenstående formulering, hvilket skaber en vis standard i fremtidige vedtægter. Dog er der i vedtægtsvejledningen også gjort plads til øvrige formål med skolevirksomheden, hvilket dermed giver friskolerne mulighed for at formulere egne mål. Det ligger derfor efter 2004 kun delvis frit for friskolerne at formulere egne mål.

\section{Øvrige formålsparagraffer}

I 18 af friskolernes øvrige formålserklæringer findes en række forskellige formål, som optræder på flere forskellige skoler gentagne gange i perioden 1980 til 2005. De hyppigst forekommende vil blive beskrevet nedenfor. Disse forskellige formål optræder overraskende ensartede i de sproglige formuleringer i betragtning af, at det drejer sig om dokumenter, som er formuleret forskellige steder på forskellige tidspunkter. Et hurtigt blik over de ca. 200 bestyrelsesmedlemmer på 33 friskoler i perioden 1980-2005 viser, at der kun ganske få steder er tale om bestyrelsesmedlemmer, som har haft flere mulighe- 
der for at påvirke flere skolers formålsvedtægter. ${ }^{16}$ Der har derfor tilsyneladende været tale om en uformel gensidig bestøvning af formuleringer af formålsparagraffer mellem skolernes bestyrelser over denne 25-årige periode. ${ }^{17}$ Det drejer sig om formuleringer, som vedrører religion, opdragelse og disciplinering af eleverne, multinational orientering, udvikling af fællesskab, sprog og integration i det danske samfund. De hyppigst forekommende formuleringer vedrører forældrenes religiøse tilhørsforhold, opdragelse og disciplinering af eleverne samt en multinational orientering.

\section{Islam i formålsparagrafferne}

11 af 23 skoler har formålsparagraffer, som indeholder punkter eller formuleringer, der omtaler eller henviser til islam. De tidligste formuleringer findes i formålsparagrafferne fra Al-Aqsa og DIA Privatskole, som blev etableret i 1980/1981, og de seneste i nærværende materiale findes i formålsparagrafferne fra Fredsskolen, som blev etableret i 2003. Andre skoler, som nævner islam i deres formålsparagraffer, er: Den Islamiske Safwa (1983), Jinnah Int. School (1984), Ahi Evran Int. School (1988), Lykkeskolen (1995), Manarul-Huda (1996), Al-Huda (1996), Al-Salahiya (1996) og Den Moderne Kulturelle Skole (1998). Det er således lidt under halvdelen af de her nævnte danske friskoler for muslimske børn fra perioden 1980 til 2005, som har direkte har referencer til islam som en del af skolernes principielle grundlag.

Efter at kunne konstatere at formålsparagrafferne hos 11 danske friskoler for muslimske børn omtaler eller henviser til islam som en del af værdigrundlaget, er det naturligt at stille spørgsmål til indhold og udviklinger i formålsparagrafferne i den 25-årige periode. Tidligt blev der lagt vægt på, at islam skulle nævnes i formålsparagrafferne. Denne accentuering lægges $\mathrm{i}$ de tidlige år som et ideologisk fokus i undervisningen, men tager senere en drejning i retning af et bredere perspektiv på elevernes almene dannelse. I formuleringerne hos Al-Aqsa, DIA Privatskole, Den Islamiske Safwa, Jinnah Int. School og Ahi Evran Int. School optræder islam som et element, der primært skal indgå som et element $\mathrm{i}$ undervisningen:

- Skolens undervisning skal foregå i overensstemmelse med islamisk religion (§ 2, stk. 2,

Vedtægter for dem selvejende institution Al Aqsa Skole i Danmark 1981).

- at undervise den islamiske religion; hvilket ikke blot er et fag som ethvert andet, men hele grundstammen i opdragelsen med udgangspunkt alene i KORANEN \& SUNNAH [Opr. kapitæler]( $§ 2$, pkt. 2, Vedtægter for den selvejende institution, Den Islamiske Safwa Skole i Danmark, Privat Grundskole, 1983). 
- at undervise den islamiske religion, og sikre at denne er grundstammen i opdragelsen med udgangspunkt i koranen og sunnah (§ 2, stk. 2.; Vedtægter for Ahi Evran International School, 1988).

Hvor islam vægtes som en del af formålet med undervisningen på skolerne i 1980'erne, antager den islamiske accent en mere bredt orienteret udformning i 1990'erne og i det nye årti. ${ }^{18}$ Disse formuleringer lægger ikke vægten på undervisningen i selve skolen, men vægter i stedet bevarelse og udvikling af muslimske identiteter og islamiske værdier hos eleverne. Formuleringerne optræder bl.a. i vedtægterne for Lykkeskolen, Al-Huda Skolen og Ørnevejens Friskole:

- At give eleverne selvagtelse ved at bevare islamiske livsværdier og deres oprindelige kulturelle positive værdier ( $(1$, stk. 2, pkt. 2; Vedtægterne for den selvejende institution Lykkeskolen, 1995).

- At medvirke til at samarbejde med forældrene, at bibringe børnene at udvikle sig fysisk, åndeligt, intellektuelt og socialt på en måde, der er i overensstemmelse med den Islamiske religion [...]At tage del i elevernes opdragelse og gøre det muligt for dem at udvikle en muslimsk identitet, der kan være en styrke og ballast i forhold til omverden $[\ldots]$ (§ 1, stk. 2, pkt. b og c; Vedtægter for den selvejende instition AlHuda Skolen, 1996). ${ }^{19}$

- Skolen har rod i den muslimske tradition og henvender sig til familier af alle nationaliteter med denne baggrund. Skolen skal i sit virke forene den muslimske tradition med nutidens krav ( $§ 2$, stk. 2; Vedtægter for den selvejende institution Ørnevejens Friskole, 2005).

Der er muligvis ikke tale om en praksisændring imellem formålsparagrafferne fra henholdsvis 1980 'erne og 1990'erne og frem, men der er væsentlige ændringer i ordlyden. I formålserklæringerne fra 1980'erne knyttes ønsket til undervisningen i klasseværelset, hvorimod erklæringerne fra 1990’erne knytter ønsket til eleven som et medlem af et større fællesskab, som indeholder både muslimer og ikke-muslimer, hvilket er et emne som kunne tages op i en anden sammenhæng.

\section{Disciplinering af eleverne $i$ vedtoegterne}

Et gennemgående element i rækken af formålsparagrafferne er skolernes ansvar som opdragere af eleverne. Næst efter formuleringer som benævner islam, så optræder formuleringer, som placerer et vist ansvar på skolen som opdrager hyppigst i det empiriske materiale. Det drejer sig om de følgende skoler: DIA Privatskole (1980), Samid Skolen (1981), Jinnah Int. School (1984), Ahi Evran School (1988), Hay Skolen (1993), Sjællands Privatskole (1996), Al-Hilal(1996), Fredsskolen(2003) og Iqra Privatskole (2005). I ni af skolernes formålsparagraffer optræder formuleringerne: "At skabe et venligt men bestemt skolemiljø, [...]" og "At tage del i elevernes opdragelse sammen med familier- 
ne." Det første af citaterne optræder i syv af de ni vedtægtserklæringer og kan findes første gang i 1980 og sidste gang i 2005. Det andet citat optræder i 1998 og 2003. I modsætning til formålsparagrafferne som omhandler islam, er der ikke den samme markante udvikling at spore, om end man sporer en mere mild formulering i slutningen af 1990’erne i forhold til skolernes ansvar på Al-Hilal og Fredsskolen. Den dominerende formulering konkretiserer skolens opgave til at skabe et venligt, men bestemt skolemiljø, hvorimod den mildere formulering udbreder ansvaret for børnenes opdragelse i retning af at være en fælles opgave mellem skolen og forældrene. Det refererede materiale tyder dog på, at det opfattes som skolens opgave at deltage i børnenes opdragelse.

\section{Multinational orientering $i$ vedtoegterne}

I forbindelse med opdragelsen af eleverne har flere friskoler formålserklæringer, som sigter efter en multinational accent. Denne accent lægges dog forskellige steder i formuleringerne. I nogle vedtægter lægges trykket på elevgruppen, og andre steder lægges trykket på et multinationalt eller multikulturelt perspektiv i undervisningen. Dog lægges vægten mest på et ønske om at kunne tilbyde undervisning til en multinational elevpopulation. Blandt skolerne DIA Privatskole (1980), Samid Skolen (1981), Sjællands Privatskole (1996), Selam Friskole (1997) og Iqra Privatskole (2005) optræder der formuleringer om målgruppen for skolens indsats: '[...] der giver børn fra forskellige samfundsklasser og nationaliteter...”. Kun Selam Friskole har en længere formulering, som understreger skolens multinationale perspektiv:

At stræbe efter at give børnene en mangedimensionel forståelse af det internationale samfund, de lever i, ved at beskæftige sig med sproglige, kulturelle og samfundsmæssige sammenhænge (Selam Friskole).

\section{Afsluttende bemærkninger}

Man kunne fortsætte denne indledningsvise gennemgang af de resterende formål (udvikling af fællesskab, sprog og integration i forhold til det danske samfund), men pga. at disse formålserklæringer kun optræder henholdsvis fire, fire og to gange i de 23 formålserklæringer, skal det ikke forsøges her. En af pointerne med nærværende artikel har været at åbne låget for kildemateriale, som kan være med til at belyse de danske friskoler for muslimske børn og disses udvikling i det danske samfund. På baggrund af den ovenstående skitse til et nærmere studie af de danske friskoler for muslimske børn mener jeg at have vist, at skolernes formålsparagraffer vidner om nogle af de forandringsprocesser, som skolerne har undergået siden 1980 og frem til 2005. 
I relation til lovpligtige formålsparagraffer er skolerne underlagt friskoleloven, hvilket konkret påvirker vedtægternes udformning, særligt efter ændringerne i friskoleloven i 2004. Fokusområdet i denne artikel har imidlertid været de øvrige formålsparagraffer. Særligt vil jeg fremhæve udviklingen i vægtningen af islam og en muslimsk identitet, som karakteriseret af et skred fra at være et undervisningsmæssigt anliggende til i højere grad at være et dannelsesmæssigt anliggende. Derudover vil jeg bemærke, at det i sig selv er interessant, at mange formuleringer i formålserklæringerne er identiske i deres ordlyd i løbet af/over hele den 25-årige periode. Eftersom der ikke er tale om lovpligtige formålsparagraffer, men om øvrige formål, vidner det i mine øjne om en udveksling af ideer og formuleringer de respektive bestyrelser imellem. 
Bilag 1

Undervisningsministeriet

Frederiksholms Kanal 21

1220 København K

Tallat Shakoor

Forskningsassistent

Center for Ungdomsforskning/Danmarks Pædagogiske Universitetsskole

Tuborgvej 164

2400 København

tallat.1ld@dpu.dk

88889927

\section{Anmodning om aktindsigt}

20-06-2006

Jeg anmoder om aktindsigt $\mathrm{i}$ bestemte dokumenter vedrørende i alt 30 frie grundskoler fra perioden 1978-2005. Anmodning vedrører flg. lukkede og eksisterende skoler:

1)Faisal Skolen

2)Kostskolen

3)Ahi International School

4)Den arabisk-islamiske skole

5)Al-Aqsa

6)DIA Privatskole,

7)Samid Skolen
16)Al-Hikma Skolen,

17)Ibn-Sinna,

18)Irchad Skole,

19)Moderne Kulturelle Skole

20) Al-Salahiya Skolen

21)Manaul Al-Huda

22)Al-Huda Skolen 
8)Iqbal International School

9)Grøndal Skolen

10)Safwa

11)Jinnah International School

12)Dansk Marokkanske Skole

13)Lykkeskolen,

14)Hay Skolen

15)Sjællands Privatskole
23)Al-Quds Skole

24)Al-Khownain,Friskole

25)Æra-Skolen

26)Iqra-Privatskole

27)Ørnevejens Friskole

28)Fredsskolen

29)Al-Hilal

30)Selam Friskole 
Jeg anmoder om aktindsigt i bestemte dokumenter for de fem første år af nedenstående skolers virke (såfremt skolerne er gået ind) inden deres femte leveår, ønsker jeg de eksisterende dokumenter):

- $\quad$ Referat fra skolens stiftende generalforsamling (hvem deltog, hvornår, hvorhenne, hvem var initiativgruppen)

- Navneoplysninger om bestyrelsesmedlemmer i skolens første fem leveår,

- $\quad$ Brand- og bygningsmyndigheders godkendelse med evt. anmærkninger af skolebygningen til undervisningsbrug (hvilke bygninger blev brugt, adresser),

- $\quad$ Vedtægter

- $\quad$ Navneliste over skoleelever for skolens første (1) leveår (hvor mange og hvem),

- $\quad$ Skolens første fem års årsregnskab (hvor kom pengene fra)

- $\quad$ Oplysninger om skolelederens navn, stilling og uddannelse i skolens første fem leveår (hvem).

Som et led i min forskning af de såkaldte "muslimske friskoler" er jeg interesseret i en række dokumenter ang. 30 af de danske friskoler for muslimer i perioden 1978-2005, for at planlægge og udføre en basal kortlægning af de muslimske friskoler i Danmark. Dette er ønskeligt for fremtidig forskning inden for det lidet kendte, men meget medieomtalte fænomen.

Jeg håber at Undervisningsministeriet kan være mig behjælpelig i denne henseende.

Med Venlig hilsen, Tallat Shakoor 


\section{Litteratur}

Balle, Thorstein \& Margaretha Balle-Petersen (reds.) 1996: Den danske friskole - en del af den grundtvig-koldske skoletradtion.

Balle, Thorstein: "stå mål med" - om det offentliges krav til indholdet af den private børneundervisning 1814 til 2001” i: http://www.historie.syd-fyn.dk/skole/ grundskoler/staa-\%20maal-med.html

Gustaffson, Kristina, 2006: Muslimsk skola, svenske vilkår, Umca, Forlaget Boreá.

Hogdson, Marshall G.S. 1974: The Venture of Islam. Conscience and History in a World Civilisation, Vol. I., Chicago.

Ihle, Annette, 2007: Magt, medborgerskab og Muslimske Friskoler i Danmark. Traditioner, idealer og politikker. Satsningsområdet "Religion i det 21. århundrede" og Institut for Tværkulturelle og Regionale Studier (ToRS), Københavns Universitet.

Jensen, Anne-Marie, 1987: 'Islamiske skoler I Danmark", in: Asta Olesen (ed.): Islam og undervisning i Danmark. Statens Humanistiske Forskningsråd, Århus Universitetsforlag.

Jensen, Tim, 2004: "Muslimske friskoler i Danmark” i: Svensk Religionshistorisk årsskrift, vol. 3.

Mandaville, Peter, 2007:"Islamic Education in Britain: Approaches to Religious Knowledge in a Pluralistic Society", in: Robert W. Hefner \& Muhammad Qasim Zaman (eds.): Schooling Islam. The Culture and Politics of Modern Muslim Education, Princeton University Press.

Mikkelsen, Flemming, 2003: "Indvandrerorganisationer i Danmark", in: Mikkelsen, Flemming (ed.): Invandrerorganisationer i Norden, Akademiet for Migrationsstudier i Danmark, Nordisk Ministerråd.

Shakoor, Tallat, 2006: "Indvandrerfriskoler i Danmark", in: Andersen, Peter B. Curt Dahlgreen,

Steffen Johannesen og Jonas Otterbeck(eds.): Religion, skole og kulturel integration $i$ Danmark og Sverige, Museum Tusculanums Forlag.

- 2005: "Muslimske Friskoler i Danmark", in: Information om indvandrere. - Årg. 9, nr. 2. - S. 20-28, Syddansk Universitet.

Simonsen, Jørgen Bæk, 1990: Islam i Danmark. Muslimske Institutioner i Danmark 1970-1990, 
Statens Humanistiske Forskningsråd, Århus Universitetsforlag.

Korsgaard, Ove 2004: Kampen om folket: et dannelsesperspektiv på dansk historie gennem 500 år, Gyldendal.

Møldrup, Hans R., 1996: Holdninger og udvikling: om de grundtvig-koldske friskoler 1970-1995, Dansk Friskoleforening.

Vejledning af 5. juli 2006 om vedtægter for friskoler og private grundskoler m.v. http://www.uvm.dk/ /media/Files/IS/PDF06/Bestyrelse_ledelse/Vedtaegter/06 0705_vedtaegter_friskoler.ashx

Tallat Shakoor er religionssociolog. Han er ansat som videnskabelig medarbejder ved Center for Ungdomsforskning, Institut for Pædagogik, Danmarks Pædagogiske Universitetsskole, Århus Universitet.

\footnotetext{
${ }^{1}$ Shakoor, Tallat, 2005: Muslimske Friskoler i Danmark I: Information om indvandrere. - Årg. 9, nr. 2. - S. 20-28; Korsgaard, Ove, 2004: Kampen om folket: et dannelsesperspektiv på dansk historie gennem 500 ar ;

Møldrup, Hans R., 1996: Holdninger og udvikling: om de grundtvig-koldske friskoler 1970-1995, Dansk Friskoleforening.

${ }^{2}$ Eftersom danske friskoler for muslimske børn er etableret og primært anvendes af immigranter og deres efterkommere fra Tyrkiet, Pakistan, Somalia og andre islamdominerede lande i Mellemøsten, så beskrives immigranterne og deres efterkommere som muslimske immigranter og efterkommere i denne artikel.

${ }^{3}$ Nærværende undersøgelse er baseret på dokumenter opnået igennem aktindsigt i flg. dokumenter fra 30 skoler i perioden 1978-2005: Referat fra skolens stiftende generalforsamling (hvem deltog, hvornår, hvorhenne, hvem var initiativgruppen); navneoplysninger om bestyrelsesmedlemmer i skolens første fem leveår), brand- og bygningsmyndigheders godkendelse med evt. anmærkninger af skolebygningen til undervisningsbrug (hvilke bygninger blev brugt, adresser), vedtægter, navneliste over skoleelever for skolens første (1) leveår (hvor mange og hvem), skolens første fem års årsregnskab (hvor kom pengene fra), oplysninger om skoleledelsens navn, stilling og uddannelse i skolens første fem leveår (hvem). Kun formålsparagrafferne er behandlet i denne artikel. Se bilag 1.

${ }^{4}$ Olesen, Asta (ed.), 1987: Islam og undervisning i Danmark. Aarhus Universitetsforlag; Bæk Simonsen, Jørgen, 1990: Islam i Danmark, Aarhus Universitetsforlag; Ihle, Annette Haaber, 2007: Magt, medborgerskab og Muslimske friskoler i Danmark. Traditioner, idealer og politikker.

${ }^{5}$ Balle, Thorstein \& Balle-Petersen, Margaretha (eds.), 1996: Den danske friskole - en del af den grundtvig-koldske skoletradition: 13 .

${ }^{6}$ I 1994, 1996, 2000 og 2003.

${ }^{7}$ Bæk Simonsen, Jørgen, 1990: Islam i Danmark, Aarhus Universitetsforlag; Shakoor, Tallat, 2006: "Indvandrerfriskoler i Danmark" i: Andersen, Peter B. Curt Dahlgreen, Steffen Johannesen og Jonas Otterbeck: Religion, skole og kulturel integration i Danmark og Sverige, Museum Tusculanums Forlag. ${ }^{8}$ Haaber Ihle, Annette, 2007: Magt, medborgerskab og Muslimske Friskoler i Danmark. Traditioner, idealer og politikker. Satsningsområdet "Religion i det 21. århundrede" og Institut for Tværkulturelle og Regionale Studier (ToRS), Københavns Universitet: 55-59.

${ }^{9}$ Haaber Ihle, Annette, 2007: Magt, medborgerskab og Muslimske Friskoler i Danmark. Traditioner, idealer og politikker. Satsningsområdet "Religion i det 21. århundrede" og Institut for Tværkulturelle og Regionale Studier (ToRS), Københavns Universitet; Shakoor, Tallat, 2006: "Indvandrerfriskoler i Danmark" i: Andersen, Peter B. Curt Dahlgreen, Steffen Johannesen og Jonas Otterbeck: Religion, skole og kulturel integration i Danmark og Sverige, Museum Tusculanums Forlag; Gustaffson, Kristina, 2004: Muslimsk skola, svenske vilkår, Umca, Forlaget Boreá; Jensen, Tim, 2004: "Muslimske friskoler i Danmark" i: Svensk Religionshistorisk årsskrift, vol. 3.; Mikkelsen, Flemming, 2003: "Indvan-
} 
drerorganisationer i Danmark" i: Mikkelsen, Flemming (ed.): Indvandrerorganisationer i Norden, Akademiet for Migrationsstudier i Danmark, Nordisk Ministerråd; Simonsen, Jørgen Bæk, 1990: Islam i Danmark. Muslimske Institutioner i Danmark 1970-1990, Statens Humanistiske Forskningsråd; Jensen, Anne-Marie, 1987: "Islamiske skoler I Danmark", in: Olesen, Asta (ed.): Islam og undervisning $i$ Danmark. Statens Humanistiske Forskningsråd, Århus Universitetsforlag.

${ }^{10}$ Mandaville, Peter, 2007: "Islamic Education in Britain: Approaches to Religious Knowledge in a Pluralistic Society”. In: Hefner, Robert W. \& Muhammad Qasim Zaman: Schooling Islam. The Culture and Politics of Modern Muslim Education. Princeton University Press.

${ }^{11}$ Haaber Ihle, Annette, 2007: Magt, Medborgerskab og Muslimske Friskoler i Danmark: 49.

${ }^{12}$ Shakoor, Tallat, 2005: Muslimske Friskoler i Danmark I: Information om indvandrere. - Årg. 9, nr. 2. - S. 20-28.

${ }^{13}$ Se eksempelvis Naquib Yossef, tidl. skoleleder på Al-Aqsa Skolen, citeret efter Olesen i: Olesen, Asta (red.): Islam i Danmark, Aarhus University Press, 1987.

${ }^{14}$ Balle, Thorstein, 2001: "stå mål med" - om det offentliges krav til indholdet af den private børneundervisning 1814 til 2001" i: http://www.historie.syd-fyn.dk/skole/grundskoler/staa-\%20maal-med.html 15 Vejledning af 5. juli 2006 om vedtægter for friskoler og private grundskoler m.v. http://www.uvm.dk/ /media/Files/IS/PDF06/Bestyrelse_ledelse/Vedtaegter/060705_vedtaegter_friskol er.ashx

${ }^{16}$ Baseret på en gennemgang af skolernes bestyrelser i skolernes første år i perioden 1978-2005.

17 Denne hypotese har jeg fremlagt tidligere i: "Indvandrerfriskoler i Danmark" In: Andersen m.fl.(Eds.): Religion, skole og kulturel integration i Danmark og Sverige. Museum Tusculanums Forlag, 2006.

${ }^{18}$ Her skal der ikke præsenteres spekulationer over, hvorfor det forholder sig sådan, eftersom dette først og fremmest er en præsentation af empiri.

${ }^{19}$ Al-Huda Skolen har flere versioner af deres vedtægter, den her refererede er den seneste. En tidligere version har en anden formulering af den ovenfor citerede formulering. I stedet for "At medvirke til, at samarbejde med forceldrene, at bibringe børnene at udvikle sig fysisk, åndeligt, intellektuelt og socialt på en måde, der er i overensstemmelse med den Islamiske religion" står der "At medvirke til, at samarbejde med forceldrene, at bibringe børnene at udvikle sig fysisk, åndeligt, intellektuelt og socialt på en måde, der er i overensstemmelse med Koranen og Sunnah”. 